\title{
Nursing diagnosis after hematopoietic stem cell transplant due to Fanconi anemia
}

\author{
Diagnósticos de enfermagem em transplantados de células-tronco hematopoéticas por anemia de Fanconi \\ Diagnósticos de enfermería en trasplantados de células madre hematopoyéticas por anemia de Fanconi
}

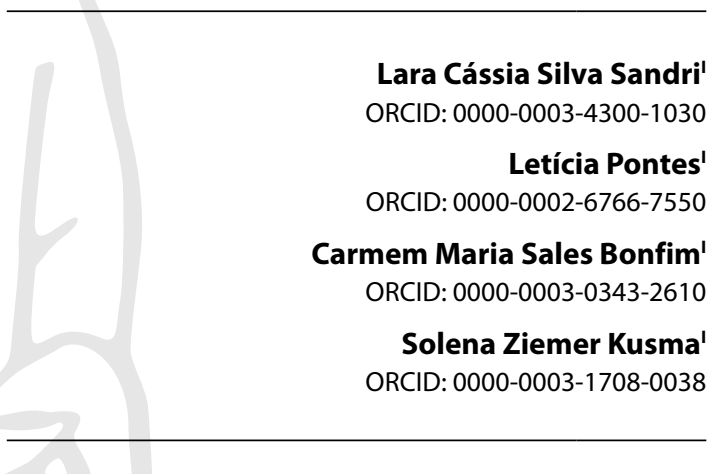

'Universidade Federal do Paraná. Curitiba, Paraná, Brazil.

How to cite this article:

Sandri LCS, Pontes L, Bonfim CMS, Kusma SZ. Nursing diagnosis after hematopoietic stem cell transplant due to Fanconi anemia. Rev Bras Enferm. 2022;75(3):e20190864. https://doi.org/10.1590/0034-7167-2019-0864

\section{Corresponding author:}

Lara Cássia Silva Sandri E-mail: laracsandri@gmail.com

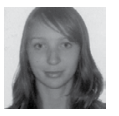

EDITOR IN CHIEF: Antonio José de Almeida Filho ASSOCIATE EDITOR: Marcos Brandão

Submission: $07-28-2020$

Approval: 08-14-2021

\begin{abstract}
Objectives: to identify nursing diagnoses in patients who underwent hematopoietic stemcell transplants due to Fanconi anemia, according to the NANDA-I taxonomy. Methods: exploratory study using a retrospective analysis of 85 records from patients who underwent hematopoietic stem-cell transplants due to Fanconi anemia, developed in a specialize transplant center in the South of Brazil. The results were analyzed using descriptive statistics. Results: 73 different diagnoses were found in 9 out of the 13 domains from the NANDA-I taxonomy. From these, 22 were in $50 \%$ or more of the patients investigated, and most of them are related to the domain Safety/Protection. Conclusions: it was possible to identify the nursing diagnosis in the patients who underwent hematopoietic stem cell transplants due to Fanconi anemia, contributing to design a plan for the care of these patients. The same was true for those with other syndromes of chromosomal instability that need to undergo this transplant.
\end{abstract}

Descriptors: Nursing Diagnosis; Nursing Process; Hematopoietic Stem Cell Transplantation; Fanconi Anemia; Nursing Care.

\section{RESUMO}

Objetivos: identificar diagnósticos de enfermagem em pacientes submetidos a transplante de células-tronco hematopoéticas por anemia de Fanconi, segundo a taxonomia da NANDA-I. Métodos: estudo exploratório mediante análise retrospectiva dos registros de 85 prontuários de pacientes submetidos a transplante de células-tronco hematopoéticas por anemia de Fanconi, desenvolvido em um centro transplantador de referência do Sul do Brasil. Analisaram-se os dados utilizando-se estatística descritiva. Resultados: identificaramse 73 diferentes diagnósticos em 9 dos 13 domínios da taxonomia da NANDA-I. Destes, 22 diagnósticos atingiram $50 \%$ ou mais dos pacientes investigados, e o maior número está relacionado ao domínio de Segurança e Proteção. Conclusões: foi possível identificar os diagnósticos de enfermagem presentes em pacientes submetidos a um transplante de células-tronco hematopoéticas por anemia de Fanconi, contribuindo para o delineamento do plano de cuidados desses pacientes, assim como para aqueles com outras síndromes de instabilidade cromossômica que necessitam ser submetidos ao transplante.

Descritores: Diagnóstico de Enfermagem; Processo de Enfermagem; Transplante de CélulasTronco Hematopoéticas; Anemia de Fanconi; Cuidado de Enfermagem.

\section{RESUMEN}

Objetivos: identificar diagnósticos de enfermería en pacientes sometidos a trasplante de células madre hematopoyéticas por anemia de Fanconi, segundo la taxonomía NANDA-I. Métodos: estudio exploratorio mediante análisis retrospectivo de registros de 85 prontuarios de pacientes sometidos a trasplante de células madre hematopoyéticas por anemia de Fanconi, desarrollado en un centro trasplantador de referencia del Sur Brasileño. Analizados los datos utilizándose estadística descriptiva. Resultados: identificaron 73 diferentes diagnósticos en 9 de los 13 dominios de la taxonomía NANDA-I. De estos, 22 diagnósticos atingieron 50\% o más de los pacientes investigados, y el mayor número está relacionado al dominio de Seguridad y Protección. Conclusiones: fue posible identificar los diagnósticos de enfermería presentes en pacientes sometidos a un trasplante de células madre hematopoyéticas por anemia de Fanconi, contribuyendo para el delineamento del plan de cuidados de esos pacientes, incluso para aquellos con otros síndromes de inestabilidad cromosómica que necesitan ser sometidos al trasplante.

Descriptores: Diagnóstico de Enfermería; Proceso de Enfermería; Trasplante de Células Madre Hematopoyéticas; Anemia de Fanconi; Atención de Enfermería. 


\section{INTRODUCTION}

Fanconi anemia (FA) is a genetic disease, generally inherited, autosomal and recessive, with a high risk of developing pancytopenia and evolving into leukemia and solid tumors ${ }^{(1-2)}$. Its incidence is estimated in nearly 3 per 1 million people born alive ${ }^{(3)}$.

Currently, the transplant of hematopoietic stem cells (HPST) is the only treatment with a perspective of hematologic cure for Fanconi anemia ${ }^{(4-5)}$, and Brazil has been an international reference in this modality ${ }^{(6)}$.

The HPST, a complex and costly procedure ${ }^{(7)}$, is characterized by the infusion of blood cells from the bone marrow, peripheral blood, or umbilical cord to correct a defect in the bone marrow, be it quantitative or qualitative ${ }^{(4)}$.

The success of this therapeutic modality depends on a qualified and integrated multidisciplinary team, including, in addition to the medical service, professionals from other fields that carry out essential actions in this process, and the actions of the nurse stand out. Due to the specificity of the actions carried out by the nursing team, the specialized actions of these professionals are essential( ${ }^{(8)}$.

Therefore, the choice and use of methods of nursing care are essential to attend to the needs of the patients, their relatives and responsible with quality, in all stages of the HPST ${ }^{(9)}$. To guide their professional practice and organize their work, nurses have been using the Systematized Nursing Care (SNC).

The SNC is considered to be a tool to manage care, since it involves aspects that transcend direct care, making it possible to evaluate the activities carried out and contributing for managerial and political decision making, focused on the excelence of care ${ }^{(10)}$. For the Federal Council of Nursing (COFEN) ${ }^{(11)}$, the SNC organizes the professional work in regard to method, people, and instrument, making it possible to operationalize the process of nursing (NP).

The NP is an instrument of the SNC, and should be the pillar, the structuring axis for the construction of knowledge and, consequently, for professional practice, since the care is an object of study of the nursing work ${ }^{(12)}$ This process is put into effect in five stages: data collection; nursing diagnosis; intervention planning; implementation of interventions; nursing evaluation.

The identification of nursing diagnoses (ND) is crucial for the nurse to develop the nursing process (NP), in according with resolution 258/2009 from the COFEN, which determines its implantation in environments where nursing care takes place ${ }^{(10)}$. In this regard, the NANDA-I taxonomy provides a way to classify and categorize areas that are concerning for nursing. Since the diagnoses are targeted at a problem, the nurses can identify opportunities to promote health or potential risks ${ }^{(13-14)}$.

Planning care according to the taxonomy mentioned has benefited several of the fields of action of nurses, including the HPST, which is a specialty that demands several forms of health care, including complex and specialized interventions ${ }^{(15)}$.

\section{OBJECTIVES}

To identify nursing diagnosis in patients who underwent hematopoietic stem cell transplants due to Fanconi anemia.

\section{METHODS}

\section{Ethical aspects}

The study followed the recommendations from Resolution $466 / 2012$ from the National Council of Health (NCS), and the project was approved by the Research Ethics Committee (REC) from the General Hospital Complex (GHC) at the Universidade Federal do Paraná (UFPR).

\section{Design, place, and period of the study}

This is an exploratory and retrospective study, based on the analysis of the records of patients who underwent HPST from 2009 to 2015, in the Service of Bone Marrow Transplants of a teaching hospital in the city of Curitiba, in the state of Paraná (PR). Data collection took place from April to November 2017, in the records of patients who received HPST from 2009 to 2015. The mean time of collection was of six hours per record, considering that the records of the entire multiprofessional team were used. The study was guided by the tool Strengthening the Reporting of Observational Studies in Epidemiology (STROBE).

\section{Population or sample; criteria of inclusion and exclusion}

The population of this study included 86 patients who received HPST, and the inclusion criteria were: have undergone a first transplant from July 2009 to July 2015; having records available for consultation; and securing an authorization from the patient, their parents, or legal representatives for participation in the study, provided by the signing of the Free and Informed Consent Form (FICF) and the Free and Informed Assent Form (FIAF).

The exclusion criteria considered patients whose records were not found or had incomplete information. One patient was excluded due to the fact he did not have available records, leading a sample of 85 patients.

The patients who underwent transplants from 2009 to 2015 due to FA were identified with the aid of the logbook of the Service of Bone Marrow Transplants from the General Hospital Complex of the Universidade Federal do Paraná (STMO/CHC/UFPR).

The Free and Informed Consent Form (FICF) and Free and Informed Assent Form (FIAF) were signed by the patient or a relative. The patients who do not live in Curitiba were approached on the day of a consultation in the outpatient clinic of the STMO or in the 5th Meeting of Fanconi Anemia, which took place in November 2017.

\section{Study protocol}

At first, the patients submitted to HPST from 2009 to 2015 due to Fanconi anemia were identified with the aid of the logbook of the transplants carried out at the STMO/CHC/UFPR. A list was formed including the name and records of these patients and delivered to the Medical and Statistical Archival Services (SAME) at the CHC/UFPR, which selected and separated the records that were then made available as the data was collected within the sector.

The data were obtained using an instrument whose variables were divided in blocks: sociodemographic data; clinical data; 
treatment and clinical complications; potential NDs from patients who underwent HPST. This tool was idealized by the research and developed with the aid of an information technology expert, using the Visual Basic (VBA) language in Microsoft Excel 97. The NDs were selected with regards to the NANDA-I 2015/2017 taxonomy.

Later, data was collected from the records of the patient according to the records of all professionals from the multidisciplinary team.

After the data was collected, diagnoses that were present in more than $50 \%$ of the patients investigated were selected. The factors related to them and their defining characteristics, according to the NANDA-I (2015), were defined, with the addition of the recommendations for care according with the NIC (2016).

\section{Analysis of results and statistics}

The analysis took place using central tendency and dispersion measures for continuous variables and absolute and relative measures for categorical variables. To do so, the software IBM ${ }^{\circ}$ SPSS $^{\circ}$, version 22, was used.

\section{RESULTS}

Among the 85 records analyzed, it was found that 46 (54.1\%) of patients were male. Their median age was 9 years old (3-39), and most were from 5 to 10 years old $(58.8 \%)$. Most were white (64.7\%), from the South of the country (58.9\%), and most of their congenital malformations was in their head and face (72.9\%).
Regarding the type of transplantation, the donors of $58.8 \%$ of patients were related to them; $21.2 \%$ of these transplants were haploidentical. The source of the hematopoietic stem cells was almost always the bone marrow (97.6\%).

$73 \mathrm{ND}$ related to nine domains were identified in varied proportions. From them, 22 affected $50 \%$ or more of the patients investigated. These diagnoses were described and explored in Table 1.

\section{DISCUSSION}

This study made it possible to identify the nursing diagnoses presented by patients who underwent hematopoietic stem cell transplants due to Fanconi anemia, among which stood out Ineffective protection, impaired skin integrity, impaired tissue integrity, impaired oral mucous membrane, impaired comfort, social isolation, risk for gastrointestinal motility, risk for infection, and risk for bleeding, all of which were present in $100 \%$ of the patients investigated.

This result is justified by the characteristics of patients with FA and patients after the transplant, which include deficient immunity ${ }^{(1)}$, worsened by the process of immunosuppression and the use of opioids, which is necessary in this type of therapy. The clinical practice, as well as the analysis of this research, shows that some NDs are related with one another. The impaired oral mucous membrane, for example, triggered the diagnosis acute pain in $97.6 \%$ of patients. Consequently, the use of opioids - the analgesics of choice at the STMO - is related to the diagnosis of Constipation.

Table 1 - Nursing diagnoses according to NANDA-I, presented by the patients with Fanconi anemia who underwent hematopoietic stem cell transplants in the bone marrow transplant service of the general hospital complex of the Universidade Federal do Paraná, 2009 to 2015

\begin{tabular}{|c|c|c|c|}
\hline DOMAIN & CATEGORY & NURSING DIAGNOSIS & FREQUENCY (\%) \\
\hline 1 - Health Promotion & 2 - Health management & - Ineffective protection & 100 \\
\hline \multirow[t]{2}{*}{2 - Nutrition } & 1 - Ingestion & $\begin{array}{l}\text { - Impaired swallowing } \\
\text { - Imbalanced nutrition: less than body re-quirements }\end{array}$ & $\begin{array}{l}72.9 \\
92.9\end{array}$ \\
\hline & 5 - Hydration & $\begin{array}{l}\text { - Risk for electrolyte imbalance } \\
\text { - Excess fluid volume }\end{array}$ & $\begin{array}{l}65.9 \\
60.0\end{array}$ \\
\hline $\begin{array}{l}3 \text { - Elimination and } \\
\text { Exchange }\end{array}$ & 2 - Gastrointestinal function & $\begin{array}{l}\text { - Risk for constipation } \\
\text { - Diarrhea } \\
\text { - Dysfunctional gastrointestinal motility } \\
\text { - Risk for dysfunctional gastrointestinal motility }\end{array}$ & $\begin{array}{l}71.8 \\
91.8 \\
80.0 \\
100\end{array}$ \\
\hline $\begin{array}{l}9 \text { - Coping/Stress } \\
\text { Tolerance }\end{array}$ & 2 - Coping responses & - Anxiety & 57.6 \\
\hline \multirow[t]{4}{*}{11 - Safety/Protection } & 1 - Infection & - Risk for infection & 100 \\
\hline & 2 - Physical injury & $\begin{array}{l}\text { - Impaired skin integrity } \\
\text { - Impaired tissue integrity } \\
\text { - Impaired oral mucous membrane } \\
\text { - Risk for falls } \\
\text { - Risk for bleeding }\end{array}$ & $\begin{array}{l}100 \\
100 \\
100 \\
96.5 \\
100\end{array}$ \\
\hline & 5 - Defensive processes & - Risk for allergy response & 84.7 \\
\hline & 6 -Thermoregulation & - Hyperthermia & 98.8 \\
\hline \multirow[t]{3}{*}{12 - Comfort } & $\begin{array}{l}\text { 1, } 2,3 \text { - Physical, environmental, and } \\
\text { social comfort }\end{array}$ & - Impaired comfort & 100 \\
\hline & 1 - Physical comfort & $\begin{array}{l}\text { - Acute pain } \\
\text { - Nausea }\end{array}$ & $\begin{array}{l}97.6 \\
95.3\end{array}$ \\
\hline & 3 - Social comfort & - Social isolation & 100 \\
\hline
\end{tabular}


In an integrative review, in the context of child cancer, clinical indicators of protection were related to the diagnosis of Ineffective protection, identifying: injured oral mucous membrane, injured gastrointestinal mucous membrane, insufficient antibody titration, repeated infections, and opportunistic infections ${ }^{(16)}$.

An injured oral mucous membrane, for example, is a clinical indicator for the increase in the risk of infections and bleeding due to the fact that the mucous membrane protection is breached. In the NANDA-I taxonomy, this ND is called Impaired oral mucous membrane ${ }^{(17)}$. It is considered to be common in antineoplastic treatments, affecting from $60 \%$ to $100 \%$ of the patients who received $\mathrm{HPST}^{(18-20)}$. In this research, all patients investigated developed mucositis in varied intensity. The most common type was 3a, which includes: moderate to intense erythema, ulceration and intense pain, making it impossible for the patient to eat for seven days or more.

In this study, the high incidence of impaired oral mucous membranes is due to the fact that most of the population are children, and, thus, are more likely to develop mucositis, which is likely to be more severe than that of adult patients ${ }^{(21)}$. Furthermore, due to the chromosomal instability associated with FA, the patients have more gastrointestinal toxicity, related to the use of methotrexate during the transplant ${ }^{(1)}$.

Therefore, the nurse must classify the conditions of the oral mucous membrane of the patients daily - reporting the characteristics, signs, and symptoms of mucositis - and registering them in the nursing evaluation. Through this investigation, interventions and criteria to manage the mucositis can be established, as well as the definition of protocols and evaluation routines for the team ${ }^{(22)}$.

The importance of developing a protocol of nursing care for mucositis stands out, considering that, with this complication, the patients show intense pain during the acute inflammatory period of mucositis. Therefore, the ND acute pain is present in these patients, impairing their quality of life during the HPST process ${ }^{(23)}$.

In a study with post-transplant children and adolescent, pain was found to be the most frequent and debilitating symptom in the context of HPST ${ }^{(24)}$, and, in this study, it was mostly associated with oral mucositis, although it was also related with abdominal pain, to the insertion of the semi-implanted central venous catheter (SICVC), and to the graft-versus-host disease (GVHD). These results are similar to the findings of another study with a similar population, which showed that the pain of patients who underwent HPST became worse due to chemotherapy side effects and to acute complications after the transplant, such as: gastrointestinal complications, oral mucositis, veno-occlusive disease, and $\mathrm{GVHD}^{(25)}$.

Due to the impact of this complication to the patient, the evaluation of the pain as a fifth vital sign, in the context of the HPST, has been considered to be a valuable strategy to provide adequate assistance. Therefore, measures to heal or relief this problem have been a constant concern of nurses.

In regard to analgesics, morphine was used in $100 \%$ of patients of this study, standing out as the systematic treatment of choice to control pain, especially the pain associated to mucositis ${ }^{(18)}$. This medication is effective in the control of pain, but its adverse effects must be monitored, such as gastrointestinal motility alterations that can lead to these NDs: Risk for dysfunctional gastrointestinal motility; Risk for constipation; and Constipation.

In a study about the perception of the nurses of the pain as treated by opioids, $41.7 \%$ of the participants mentioned constipation as one of the main side effects of the medication ${ }^{(26)}$. Understanding the potential reactions, and in accordance with Article 78 from the COFEN Resolution 564/2017, which forbids the use of medications with no knowledge of its potential risks, nurses must investigate, daily, the frequency and the characteristics of the eliminations of the patient, as well as the presence of masses and/or pain at the palpation of the abdomen and diminishedair-liquid sounds.

However, although this opioid can cause undesirable effects, it is not replaced due to the fact that the other standard analgesics do not meet the need of the patients or require oral ingestion, which is highly compromised during this period.

In addition to the use of morphine, effective strategies to relief acute pain and the discomfort used in the field of this study are the adoption of non-pharmacological measures, such as intensifying oral hygiene with soft toothbrushes or alcohol-free mouth washes; offering glutamine, iced tea, or chamomile tea; and applying lip balm ${ }^{(27-28)}$.

Despite the actions described, this study showed that patients with pain related to oral mucositis evolve to refuse eating, and as a result, other NDs emerge. Among them, the ND impaired swallowing, which is the main cause for the development of the ND impaired nutrition (also found in this research), which occurs when the oral ingestion is less than the body requires.

The search for strategies to minimize nutritional alterations reiterates the importance of multidisciplinarity in the Bone Marrow Transplant Service, since the surveying of NDs may go beyond the nursing auxiliaries and the nurses themselves, aiding other health workers in the identification of areas where joint action is ideal ${ }^{(14)}$.

Coming back to the ND impaired oral mucous membrane, as mentioned above, it is also associated to the Risk of bleeding, which, in the context of the patients of this research, is worsened by thrombocytopenia and by the need to replace the blood components, as described in literature ${ }^{(29)}$. It is worth considering that the nurse is responsible for planning, executing, coordinating, supervising, and evaluating the hemotherapy, according to the technical norm approved by the Resolution COFEN No. 0511, from 2016.

It stands out that, in addition to the thrombocytopenia, all patients in this study also developed neutropenia, which can lead to severe infectious complications, thus increasing mortality. Considering the infection as one of the main complications of $\mathrm{HPST}^{(23)}$, the planning of nursing care based on the ND Risk for infection must be a damage control priority for all professionals in the multidisciplinary team, and visitors of the patient.

In addition to the neutropenia, the FA itself, as a chronic disease, is considered to be a risk factor for the ND Risk for infection, and the same is true for the insertion of semi-implanted central venous catheters, the diminution in hemoglobin levels, and leukopenia.

The ND Social isolation, which involved the patients transplanted in the place of this study, takes place when the patient cannot be present in daily activities (such as going to work and school) 
and social activities. It also happens when no persons with an affective relation with the patient, such as relatives and friends, can be present, due to the restriction of visitors. Although Law No. 106/2009 enacts the right for permanent visitation during the hospitalization of 18-year-old or younger patients, it should be highlighted that one of the duties of the nurse is to evaluate each case and detect the need of visitors for adult patients as well, since this favors the social and family wellbeing, needed during the therapy ${ }^{(30)}$.

The ND Anxiety can be identified in different stages of the HPST process, such as in the moment of hospitalization, when the anxiety is related to the lack of knowledge about what is to come. This is followed by the implantation of a semi-implanted central venous catheter and the infusion of $\mathrm{HSC}^{(31)}$. Furthermore, it is impossible to be certain that the graft will be successful, not to mention complications associated with the treatment and the potential changes in body image, which can make the patient anxious.

The process of hospital discharge also generates anxiety, due to the fear that one will not be capable of adequately providing care and to the fear of rehospitalization. Therefore, the planning of care, in this stage, should be focused on the guidance of home care, to reduce anxiety, improve the adherence to the therapeutic plans, and, consequently, the health conditions ${ }^{(32)}$.

In this study, acute GVHD affected 11 patients, in most cases affecting the skin and causing the ND Impaired skin integrity in some patients. The diagnosis of acute GVHD can also be considered to be a factor that triggers the ND Anxiety ${ }^{(33)}$.

However, considering that the NDs Impaired skin integrity and Impaired tissue integrity affected all patients, the SICVC was considered to be the main factor associated with these diagnoses. This apparatus is widely used in the HPST processes, and is considered essential due to the venous fragility and the need for simultaneous infusions of incompatible solutions ${ }^{(34-36)}$. An article about the use of this device in patients who undergo HPST stated that its management is a responsibility of the nursing service, and that these professionals must be attentive to the discontinuity of the tissue in its place of insertion, planning actions to prevent complications $^{(36)}$.

However, as this study shows, the discontinuity of the skin of these patients is also indicated by drying, flaking, or dermatitis, requiring attention from nursing to guide endogenous and exogenous hydration, maintaining areas of contact free from humidity, and mobilizing the patient on the bed.

This mobilization is also characterized as a strategy that contributes with the other NDs, such as Dysfunctional gastrointestinal motility in the presence of constipation. Among the defining characteristics of the ND, in addition to constipation, there are also the NDs Nausea and Diarrhea. These diagnoses are present especially in the stage before the HPST, since they are frequent adverse reactions to the chemotherapy ${ }^{(37)}$. They require urgent care from the nursing professionals due to the fact that they significantly compromise the metabolic functioning, as well as the wellbeing of the patients affected.

Regarding nausea, the patient with this symptom, which is so pervasive in the HPST process, can reap benefits from non-pharmacological measures, such as slow and deep breathing, the technique of distracting and relaxing, and the reduction of unpleasant smells, sounds, and visual stimuli(38).

Nausea triggers vomits, which, as in the case of diarrhea, are risk factors for the ND Risk for electrolyte imbalance, which this study associated with the treatment regimen. This issue has been prevented, in the place where the research was carried out, by daily blood collections from the patients, by the nursing team, to evaluate the need for extra electrolytes, according to the proposal of a previous study, carried out in the same location as the research ${ }^{(27)}$.

Another ND that stood out was the Excess fluid volume, which is especially associated with hyper-hydration, an essential measure to prevent the toxic effects of cyclophosphamide. This requires the nurse to plan an assistance that detects changes such as weight gain and edema, which indicate increased an parenteral volume ${ }^{(27,39)}$. Thus, practices that are paramount to identify complications early include checking the hydric balance every 24 hours, checking the body weight three times a day, and maintaining a tight control on eliminations.

The NDs discussed show that these patients may be experiencing discomfort, which was confirmed by the fact that $100 \%$ of patients have the ND Impaired comfort. This diagnoses may be related to several stressing factors, such as: the environment, the imposition of norms and routine, the loss of privacy and freedom, and the exposure to invasive and unpleasant procedures ${ }^{(40)}$.

It is important to highlight that aspects other than clinical ones, should be valued when a nursing care of excellence is proposed $^{(14)}$, and is recommended to the complex treatment centers, such as the HPST.

\section{Study limitations}

The limitation of the study was the reduced number of nursing diagnoses registered. This required the researcher to explore other records, such as hydric balance, notes from the nursing team, and clinical progressions from the multiprofessional team, in the search for related factors and defining characteristics of potential NDs that were not identified or not registered by the direct assistance nurses.

\section{Contributions to the field}

The investigation of this population aims to fill in a gap in studies that consider the characteristics and individual needs of patients with FA who undergo HPST.

Considering that the STMO/CHC/UFPR has one of the longer experiences in the world with HPST in patients with FA, this investigation makes it possible for nurses to use the findings to design a plan for care, both for these patients and for others with chromosomal instability syndromes who must be submitted to this type of treatment.

\section{CONCLUSIONS}

It was possible to identify the nursing diagnoses according to the taxonomy of NANDA International Inc. (NANDA-I), found in patients who underwent HPST due to FA. Most NDs were related 
to the Domain Safety/Protection, which justifies a strict nursing care to these patients, considering the diminished ability of their organisms to defend against internal and/or external threats.

The identification of the NDs to plan the care of patients who underwent HPST allows the nurse to get to know the particularities of the patients they are caring for, and, therefore, to improve substantially the quality of care provided to patients who underwent this type of therapy.

This study recommends that there should be more investment in the formation of nurses and education during the service, in order to qualify the nurses to use the NP as an essential tool to plan care.

\section{REFERENCES}

1. Pasquini R. Transplante de células-tronco hematopoéticas para as anemias aplásticas adquiridas e constitucionais. In: Voltarelli JC, Pasquini R, Ortega ET. Transplante de células-tronco hematopoéticas. São Paulo: Atheneu; 2009. p. 233-257.

2. Velardi A, Locatelli F. Princípios e indicações clínicas do transplante de células-tronco hematopoiéticas. In: Kliegman RM, Stanton BMD, St Geme J, Schor NF. Nelson tratado de pediatria. Vol. 1. Rio de Janeiro: Elsevier; 2014. p. 757-760.

3. Sociedade Argentina de Hematologia. Guia de diagnostico y tratamiento [Internet]. [Buenos Aires]: SAH; 2015 [cited 2017 Jul 16]. Available from: http://sah.org.ar/docs/Guia-Completa-2015.pdf

4. Medeiros LA, Pasquini R. Anemia aplásica adquirida e anemia de Fanconi: diretrizes brasileiras em transplante de células-tronco hematopoéticas. Rev Bras Hematol Hemoter. 2010:32(suppl 1):40-5. https://doi.org/10.1590/S1516-84842010005000064

5. Freedman MH. As Pancitopenias hereditárias. In: In: Kliegman RM, Stanton BMD, St Geme J, Schor NF. Nelson tratado de pediatria. Vol. 2. Rio de Janeiro: Elsevier; 2014. p. 1682-88.

6. Seber A, Bonfim CMS, Daudt LE, Gouveia RV, Ginani VC, Mauad M, et al. Indicações de transplante de células-tronco hematopoéticas em pediatria: consenso apresentado no I encontro de diretrizes brasileiras em transplante de células-tronco hematopoéticas. Rev Bras Hematol Hemoter. 2009;32(3):225-39. https://doi.org/10.1590/S1516-84842010005000083

7. Bonfim CMS. Análise das complicações tardias após o transplante de células-tronco hematopoéticas em pacientes com anemia de Fanconi [master's thesis]. Curitiba: Universidade Federal do Paraná; 2014[cited 2017 May 10]. 108 p. Available from: https://acervodigital.ufpr.br/ bitstream/handle/1884/37101/R\%20-\%20T\%20-\%20CARMEM\%20MARIA\%20SALES\%20BONFIM.pdf?sequence=3\&isAllowed=y

8. Timurağaoğlu A. The role of the nurses and technicians for stem cell mobilisation and collection. Transfus Apher Sci. 2015;53(1):30-3. https:// doi.org/10.1016/j.transci.2015.05.012

9. Cruz KRP, Santos ACF. Assistência de enfermagem ao paciente submetido a transplante de células tronco hematopoiéticas (TCTH). Rev Uningá [Internet]. 2018[cited 2017 Jan 4];37(1):133-46. Available from: http://revista.uninga.br/index.php/uninga/article/view/1117

10. Gutiérrez MGR, Morais SCRV. Systematization of nursing care and the formation of professional identity. Rev Bras Enferm. 2017;70(2):436-41. https://doi.org/10.1590/0034-7167-2016-0515

11. Conselho Federal de Enfermagem (BR). Resolução Cofen-358/2009. Dispõe sobre a Sistematização da Assistência de Enfermagem e a implementação do Processo de Enfermagem em ambientes, públicos ou privados, em que ocorre o cuidado profissional de Enfermagem, e dá outras providências [Internet]. Brasília, DF: Cofen; 2009[cited 2017 Jun 19]. Available from: http://www.cofen.gov.br/resoluocofen-3582009_4384.html

12. Garcia TR. Sistematização da Assistência de Enfermagem: aspecto substantivo da prática profissional [Editorial]. Esc Anna Nery. 2016;20(1):510. https://doi.org/10.5935/1414-8145.20160001

13. Herdman H. Mudanças na terminologia da Nanda Internacional. In: Nanda Internacional. Diagnósticos de enfermagem da Nanda: definições e classificações 2015-2017. 10a ed. Porto Alegre: Artmed; 2015. p. 1-30.

14. Gallagher-Lepak S. Fundamentos do diagnóstico de enfermagem. In: Nanda Internacional. Diagnósticos de enfermagem da Nanda: definições e classificações 2015-2017. 10a ed. Porto Alegre: Artmed; 2015.

15. Lima K, Bernardino E. O cuidado de Enfermagem em unidade de transplante de células-tronco hematopoéticas. Texto Contexto Enferm. 2014;23(4):845-53. https://doi.org/10.1590/0104-07072014000440013

16. Nunes MM, Leandro TA, Lopes MVO, Silva VM. Indicadores clínicos do diagnóstico de enfermagem: proteção ineficaz em adolescentes com câncer. Rev Bras Enferm. 2017;70(6):1401-7. https://doi.org/10.1590/0034-7167-2016-0571

17. Nanda Internacional. Diagnósticos de enfermagem da Nanda: definições e classificações 2015-2017. 10a ed. Porto Alegre: Artmed; 2015.

18. Vigorito AC, Corrêa MEP. Mucosite. In: Voltarelli JC, Pasquini R, Ortega ET. Transplante de células-tronco hematopoéticas. São Paulo: Atheneu; 2009. p. 815-824.

19. Sasada INV, Munerato MC, Gregianin LJ. Mucosite oral em crianças com câncer: revisão de literatura. RFO (Passo Fundo). 2013;18(3):345-50. https://doi.org/10.5335/rfo.v18i3.3338

20. Mello WR. Análise dos fatores que influenciaram o desenvolvimento da mucosite oral em transplante de células-tronco hematopoiéticas autólogo [Dissertation]. São Paulo: Universidade de São Paulo; 2016. https://doi.org/10.11606/D.5.2016.tde-19122016-141644

21. Hespanhol FL, Tinoco EMB, Teixeira HGC, Falabella MEV, Assis NMSP. Manifestações bucais em pacientes submetidos a quimioterapia. Cienc Saude Colet. 2010;15(suppl 1):1085-94. https://doi.org/10.1590/S1413-81232010000700016 
22. Carlucci VDS, Braga FTMM, Reis PED, Silveira RCCP. Nursing care provided to hematologic cancer patients receiving high-dose chemotherapy: an integrative review. J Nurs UFPE. 2016;10(3):1544-55. https://doi.org/10.5205/1981-8963-v10i3a11096p1544-1555-2016

23. Machado CAM, Proença SF, Marques ACB, Mantovani MF, Guimarães PRB. Quality of life of patients submitted to autologous and allogeneic stem cell transplant in hospitalization. Enferm Glob. 2018;17(52):401-45. https://doi.org/10.6018/eglobal.17.4.304281

24. Sousa GCC, Mercês NNA, Silva LAGP, Macedo A. Gerenciamento da dor de crianças e adolescentes no período pós-transplante de célulastronco hematopoéticas: revisão integrativa. Enferm Glob. 2019;(53):551-66. https://doi.org/10.6018/eglobal.18.1.302991

25. Vasquenza K, Ruble K, Chen A, Billett C, Kozlowki L, Atwater S, et al. Pain management for children during bone marrow and stem cell transplantation. Pain Manag Nurs. 2015;16(3):156-62. https://doi.org/10.1016/j.pmn.2014.05.005

26. Posso MBS, Giaretta VMA, Santanna ALG, Ranzani RCM, Gouvea ÁL. Nurses' perception of the management of chronic non-malignant pain with opioids. Rev Dor. 2013;14(1):7-11. https://doi.org/10.1590/S1806-00132013000100003

27. Ortega ETT, Stelmatchuk AM, Cristoff C. Assistência de enfermagem em transplante de células-tronco hematopoéticas. In: Voltarelli JC, Pasquini R, Ortega ET. Transplante de células-tronco hematopoéticas. São Paulo: Editora Atheneu; 2009. p. 1031-1098.

28. Tsujimoto T, Yamamoto Y, Wasa M, Takenaka Y, Nakahara S, et al. L-glutamine decreases the severity of mucositis induced by chemoradiotherapy in patients with locally advanced head and neck cancer: a double-blind, randomized, placebo-controlled trial. Oncol Rep. 2015;33(1):33-9. https://doi.org/10.3892/or.2014.3564

29. Zanis Neto J, Calixto RF, Ostronoff M. Citopenias hematológicas e falha de enxertia pós transplante de células-tronco hematopoéticas. In: Voltarelli JC, Pasquini R, Ortega ET. Transplante de células-tronco hematopoéticas. São Paulo: Atheneu; 2009. p. 631-651.

30. Rocha V. Qualidade de vida de pacientes submetidos ao Transplante de Células-Tronco Hematopoiéticas no período de hospitalização [Dissertation]. Curitiba: Universidade Federal do Paraná; 2014[cited 2017 May 10]. Available from: https://acervodigital.ufpr.br/bitstream/ handle/1884/37251/R\%20-\%20D\%20-\%20VANESSA\%20DA\%20ROCHA.pdf?sequence=3\&isAllowed=y

31. Oliveira EA Mastropietro AP, Santos MA, Sponholz Jr A, Voltarelli JC. Intervenções da psicologia, psiquiatria e terapia ocupacional no transplante de células-tronco hematopoéticas. In: Voltarelli JC, Pasquini R, Ortega ET. Transplante de células-tronco hematopoéticas. São Paulo: Atheneu; 2009. p. 1099-118.

32. Lima AP. Alta responsável: tecnologia educacional para pacientes e cuidadores [dissertation]. Curitiba: Universidade Federal do Paraná; 2018[cited 2019 Jan 10]. Available from: https://www.prppg.ufpr.br/siga/visitante/trabalhoConclusaoWS?idpessoal=54967\&idprograma=40 001016073P0\&anobase $=2018 \&$ idtc $=25$

33. Araújo SNM, Luz MHBA, Silva GRF, Andrade EMLR, Nunes LCC, Moura RO. Cancer patients with oral mucositis: challenges for nursingcare. Rev Latino-Am Enfermagem. 2015;23(2):267-74. https://doi.org/10.1590/0104-1169.0090.2551

34. Infusion Nurses Society. Infusion Nursing standards of practice [Internet]. Norwood, 2011 [cited 2017 Jan 10]. Available from: http://incativ. es/documentos/guias/INS_Standards_of_Practice_2011[1].pdf

35. Barreta LM, Beccaria LM, Cesarino CB, Pinto MH. Complications of central venous catheter in patients transplanted with hematopoietic stem cells in a specialized service. Rev Latino-Am Enferm. 2016;24:e2698. https://doi.org/10.1590/1518-8345.0547.2698

36. Pontes L, Silva SR, Lima AP, Sandri LCS, Batistela AP, Danski MTR. Incidents related to the Hickman ${ }^{\circledast}$ catheter: identification of damages. Rev Bras Enferm. 2018;71(4):915-1920. https://doi.org/10.1590/0034-7167-2017-0051

37. Ortega E. Compêndio de enfermagem em transplante de células tronco-hematopoéticas: rotinas e procedimentos em cuidados essenciais e em complicações. Curitiba: Maio; 2004.

38. Pompeo DA, Nicolussi AC, Galvão CM, Sawada NO. Intervenções de enfermagem para náusea e vômito no período pós-operatório imediato. Acta Paul Enferm. 2007;20(2):191-8. https://doi.org/10.1590/S0103-21002007000200013.

39. Sturaro D. Aspectos farmacológicos do transplante de células-tronco hematopoéticas. In: Voltarelli JC, Pasquini R, Ortega ET. Transplante de células-tronco hematopoéticas. São Paulo: Atheneu; 2009. p. 1177-1209.

40. Cruz TC, Mattos NCPM, Nascimento NS, Marques SS, Rezende CR, Silva CMS. Evaluation of quality of life of patients hospitalized with leukemia and lymphoma. Rev Pesqui Fisioter. 2018;8(1):94-100. https://doi.org/10.17267/2238-2704rpf.v8i1.1789 